Research article

\title{
Mechanisms of desiccation tolerance in the bromeliad Pitcairnia burchellii Mez: biochemical adjustments and structural changes
}

\author{
Evandro Alves Vieira ${ }^{\mathrm{a}, *}$, Kleber Resende Silva $^{\mathrm{b}}$, Aline Oriani $^{\mathrm{b}}$, Camila Fernandes Moro ${ }^{\mathrm{c}}$, \\ Marcia Regina Braga ${ }^{a}$ \\ ${ }^{a}$ Núcleo de Pesquisa em Fisiologia e Bioquímica de Plantas, Instituto de Botânica, São Paulo, SP, Brazil \\ b Departamento de Botânica, Instituto de Biociências, Universidade Estadual Paulista, Rio Claro, SP, Brazil \\ c Programa de Pós-Graduação em Biologia Celular e Estrutural, Universidade Estadual de Campinas, SP, Brazil
}

\section{A R T I C L E I N F O}

\section{Keywords:}

Water storage tissue

Starch

Secondary metabolism

Antioxidant substances

Cell wall

Desiccation tolerance

Bromeliaceae

\begin{abstract}
A B S T R A C T
Rocky outcrops represent the diversity center of vascular desiccation tolerant (DT) plants. Vegetation in this environment is exposed to an extended dry season and extreme conditions due to rocky soils and high sun exposure. In this study, we demonstrated that Pitcairnia burchellii, a bromeliad from rocky outcrops, tolerates intense desiccation for about 90 days due to strategies as accumulation of compatible osmolytes and antioxidant substances together with leaf morphological changes. In dehydrated plants, an increase in antioxidant activity was observed and the vacuolization of parenchyma cells was accompanied by proline accumulation in leaves and rhizomes. Precursors related to phenylpropanoid pathway increased significantly during plant dehydration. Accordingly, increases in anthocyanin and phenolic contents as well as lignin deposition were observed in leaves of dehydrated plants. Cell divisions and a decrease in stored starch were observed in the rhizomes indicating starch mobilization. Anatomical analyses revealed the presence of a more developed water-storage tissue in dehydrated leaves. During desiccation, leaves curl upwards and the adaxial V deep water-storage tissue is supported by two larger lateral vascular bundles. Cell wall folding and an increased proportion of arabinosecontaining polymers was observed in leaves under dehydration, suggesting increasing of cell wall flexibility during desiccation. Such biochemical and morphological changes are consistent with the ability of $P$. burchellii to tolerate intense desiccation and behave as a resurrection species.
\end{abstract}

\section{Introduction}

The Brazilian cerrado is a savanna-like biome exposed to a regular and predictable drought season in which the vegetation is subjected to a prolonged period of water deficit (Franco et al., 2014). In the xeric savanna sites, rainfall deficit over several years results in the depletion of soil moisture, inducing plants to morpho-physiological adjustments to tolerate severe drought (Galmés et al., 2012). Rocky outcrops present as main characteristics the almost complete absence of soil cover and great topographic heterogeneity, promoting the establishment of a vegetation type distinct from that of contiguous areas (Parmentier, 2003).

The vegetation of rocky outcrops is composed predominantly of herbaceous-shrub species, growing in Litholic Neosols, in outcrops slots, or directly on the rocks. Rupicolous Araceae, bromeliads and orchids form a typical flora, with many endemic and rare species presenting xeromorphic characteristics (Carvalho et al., 2012). Many of these plants are perennial and their biomass is stored in a great diversity of underground organs (rhizomes, rhizophores, bulbs, among others). Starch and other polysaccharides, besides nitrogen, are common storage compounds found in these underground organs, allowing the regeneration of individual plants and vegetative propagation after seasonal droughts or other environmental disturbances (Moraes et al., 2016).

Water deficiency responses involve a complex interaction of physical and metabolic processes in cells, tissues and organs (Lawlor and Cornic, 2002). However, the desiccation tolerance phenomenon depends on the tolerated degree of dehydration and on the capacity of rapid rehydration, which are related to the tissue stability and longevity in the dry state (Gaff and Oliver, 2013). The intensity of the damage resulting from mechanical stress depends on factors such as the adhesion strength between plasmalemma and cell wall, the degree of disruption of the plasma membrane, and the cell wall flexibility (Gall et al., 2015). Moore et al. (2006), studying desiccated leaves of Myrothamnus flabellifolia (Myrothamnaceae), showed an increased cell wall

\footnotetext{
* Corresponding author.

E-mail address: evieirae@gmail.com (E.A. Vieira).
} 
flexibility associated with changes in pectins. The authors emphasize that the proportion of arabinose-containing polymers, which have high flexibility and capacity of water absorption, seems to be decisive for leaf rehydration after the drying period.

Resurrection plants developed enzymatic and non-enzymatic mechanisms to avoid damages caused by reactive oxygen species (ROS) (Farrant et al., 2015). The enzymatic mechanism is formed by superoxide dismutase, catalase and peroxidase, among others. The non-enzymatic mechanism includes carotenoids, ascorbic acid, tocopherols, and oxidized and reduced glutathione (Dinakar and Bartels, 2013). Under conditions of moderate stress, the radicals are efficiently eliminated by the antioxidant defense system. However, during periods of severe water stress, such radical disposal system becomes saturated by increasing ROS production rate, and damages are unavoidable (Mundree et al., 2002).

A strategy used by desiccation tolerant species to cope with water deficit is the great capacity to produce and accumulate osmotically active compounds. These compounds act replacing the water lost during the drying process and protecting tissues against the deleterious effects of high ion amounts (Gaff and Oliver, 2013), maintaining the stability of the membranes in the dehydrated state (Hoekstra et al., 2001). In Eragrostis nidenses (Poaceae), Vander-Willigen et al. (2004) demonstrated that the mechanical stress is avoided by the wall folding regulation in mesophyll while the volume of the bundle sheath cells is maintained by the accumulation of proline and proteins in small vacuoles.

Pitcairnia burchellii Mez is an endemic Brazilian terrestrial bromeliad exhibiting xeromorphic characteristics like thorns at the base of the leaves and a rhizome as underground storage organ. It occurs in the North and Midwest Brazil, frequently in rocky outcrops of cerrado (Forzza et al., 2015) in slots or directly on the rock. Recently, we demonstrated that $P$. burchellii is a resurrection plant as it tolerates long periods of protoplasmic dehydration without suffering permanent injuries, recovering its metabolic competence after rehydration (Vieira et al., 2017b). The aim of this study was to evaluate the metabolic adjustments and structural changes in leaves and rhizomes of $P$. burchellii subjected to dehydration and rehydration. We analyzed anatomical characteristics and changes in biochemical parameters and showed that $P$. burchellii plants exhibit alternative dormancy strategies based on starch accumulation in the final stages of the desiccation process.

\section{Materials and methods}

\subsection{Plant material and water deficit conditions}

Plants of Pitcairnia burchellii Mez were collected in rocky outcrops in a cerrado area located in Coxim-MS, Brazil ( $18^{\circ} 28^{\prime} 53.21^{\prime \prime} \mathrm{S}, 54^{\circ}$ $45^{\prime} 32.85^{\prime \prime} \mathrm{W}$ ), and maintained in a greenhouse of the Department of Plant Physiology and Biochemistry, Institute of Botany, São Paulo, Brazil, in $5.0 \mathrm{~L}$ pots filled with organic soil. The experiment was carried out in a completely randomized design and consisted of 30 plants submitted to desiccation during 90 days, followed by rehydration. Analyses were performed at 0, 30, 60 and $90 \mathrm{~d}$ during desiccation and $192 \mathrm{~h}(8 \mathrm{~d})$ after rehydration; all extractions and analyses were performed on five leaves and three rhizomes per sampling time. Biochemical and structural analyses were performed in the middle portion of fully expanded leaves, positioned in the third row from the base to the apex of the rosette, and in the middle portion of the rhizomes.

\subsection{Relative water content (RWC)}

Relative water content was estimated in two leaves per sampling time and used as reference to evaluate the water status of the plants, using the formula: RWC $(\%)=($ FW-DW/TW-DW $) \times 100$, where FW,
DW and TW correspond to fresh, dry and turgid weight mass, respectively.

\subsection{Phenylpropanoid pathway metabolite analyses}

The main precursors of the phenylpropanoid pathway were analyzed in leaves by gas chromatography and mass spectrometry (GC/ MS), according to Roessner et al. (2001), with minor modifications. Samples of $100 \mathrm{mg}$ of fresh leaves were extracted in $500 \mu \mathrm{l}$ of methanol: chloroform: water (12: $5: 1 \mathrm{v} / \mathrm{v} / \mathrm{v})$ with the addition of $50 \mu \mathrm{l}$ of adonitol $\left(0.2 \mathrm{mg} \mathrm{ml}^{-1}\right)$ as internal standard. The mixture was incubated at $60{ }^{\circ} \mathrm{C}$, shaken for $30 \mathrm{~min}$ and centrifuged at $13.000 \mathrm{~g}$ for $5 \mathrm{~min}$. Following, $350 \mu \mathrm{l}$ of water was added to $350 \mu \mathrm{l}$ of the collected supernatant for polar phase separation. Aliquots of $300 \mu \mathrm{l}$ were dried and derivatized with pyridine and $\mathrm{N}$, O-Bis(trimethylsilyl)trifluoroacetamide (BSTFA), and shaken for $1 \mathrm{~h}$ at $75{ }^{\circ} \mathrm{C}$. Samples were analyzed on an Agilent 7890 gas chromatograph coupled to a Leco Pegasus 2 time-offlight mass spectrometer (LECO, St. Joseph, MI, USA) and a Combi-PAL autosampler (Agilent Technologies GmbH, Waldbronn, Germany). Peak detection, retention time and library matching were performed using Target Search R-package. Chromatograms were exported to Leco ChromaTOF software (version 3.25) and the metabolites were quantified by the peak intensity of a selective mass.

\subsection{Anthocyanin content}

Anthocyanin quantification was performed in dried leaves (15 mg), using $1 \mathrm{ml}$ of acidified methanol (15\% HCL v/v) and overnight stirring at room temperature. Anthocyanin containing basil extract $(150 \mu \mathrm{l})$ was added to $1 \mathrm{~mL}$ of acidified methanol and its absorbance was read at $535 \mathrm{~nm}$. Cyanidin-3-glucoside in acidified methanol was used as standard and total anthocyanin concentration was evaluated using a slightly modified version of Abdel-Aal and Huel (1999).

\subsection{Proline analysis}

Leaves and rhizomes were lyophilized, milled, weighed (200 mg), and immersed in $80 \%$ ethanol; the mixture was homogenized and incubated in a water bath at $80{ }^{\circ} \mathrm{C}$ for $15 \mathrm{~min}$. After centrifugation at $3000 \mathrm{~g}$ for $15 \mathrm{~min}$, the supernatants were combined and concentrated on a rotary evaporator (R-215, Buchi, Switzerland). The extracts were taken up in distilled water and proline content was determined according to Bates et al. (1973) based on proline to ninhydrin reaction at $520 \mathrm{~nm}$, using L-proline (Sigma-Aldrich) as standard.

\subsection{Phenol content and antioxidant activity}

The Total phenols were quantified in samples of leaves and rhizomes oven dried for $48 \mathrm{~h}$ at $50{ }^{\circ} \mathrm{C}$. The material $(20 \mathrm{mg}$ ) was mixed with $1 \mathrm{~mL}$ of $80 \%$ aqueous methanol and shaken overnight at room temperature. The mix was centrifuged at $13.000 \mathrm{~g}$ for $20 \mathrm{~min}$ and the supernatant was collected for phenol quantification according to Ainsworth and Gillespie (2007), based on Folin-Ciocalteau reagent, and using gallic acid as standard. Samples were submitted to extraction as described in item 2.4 and tested for antioxidant activity through capture of the radical 2,2-diphenyl-1-picrylhydrazyle (DPPH, Sigma-Aldrich $^{\circ}$ ). Quantitative analysis was done by adding $71.4 \mu$ of a methanol solution of DPPH $(0.3 \mathrm{mM})$ and $178.5 \mu \mathrm{l}$ of the extract. Methanol was used as negative control and Quercitin (Sigma-Aldrich ${ }^{\circ}$ ) at $5 \mu \mathrm{gl}^{-1}$ as positive control. The microplate was maintained at room temperature and the absorbance at $518 \mathrm{~nm}$ was measured after $5 \mathrm{~min}$ in an ELISA reader (KC4-Bio-Tek Instruments, Inc., USA).

\subsection{Glycosyl composition and glycosyl linkage analyses of leaf cell walls}

Leaf cell walls were extracted from leaves sampled at 0, 60 and 90 

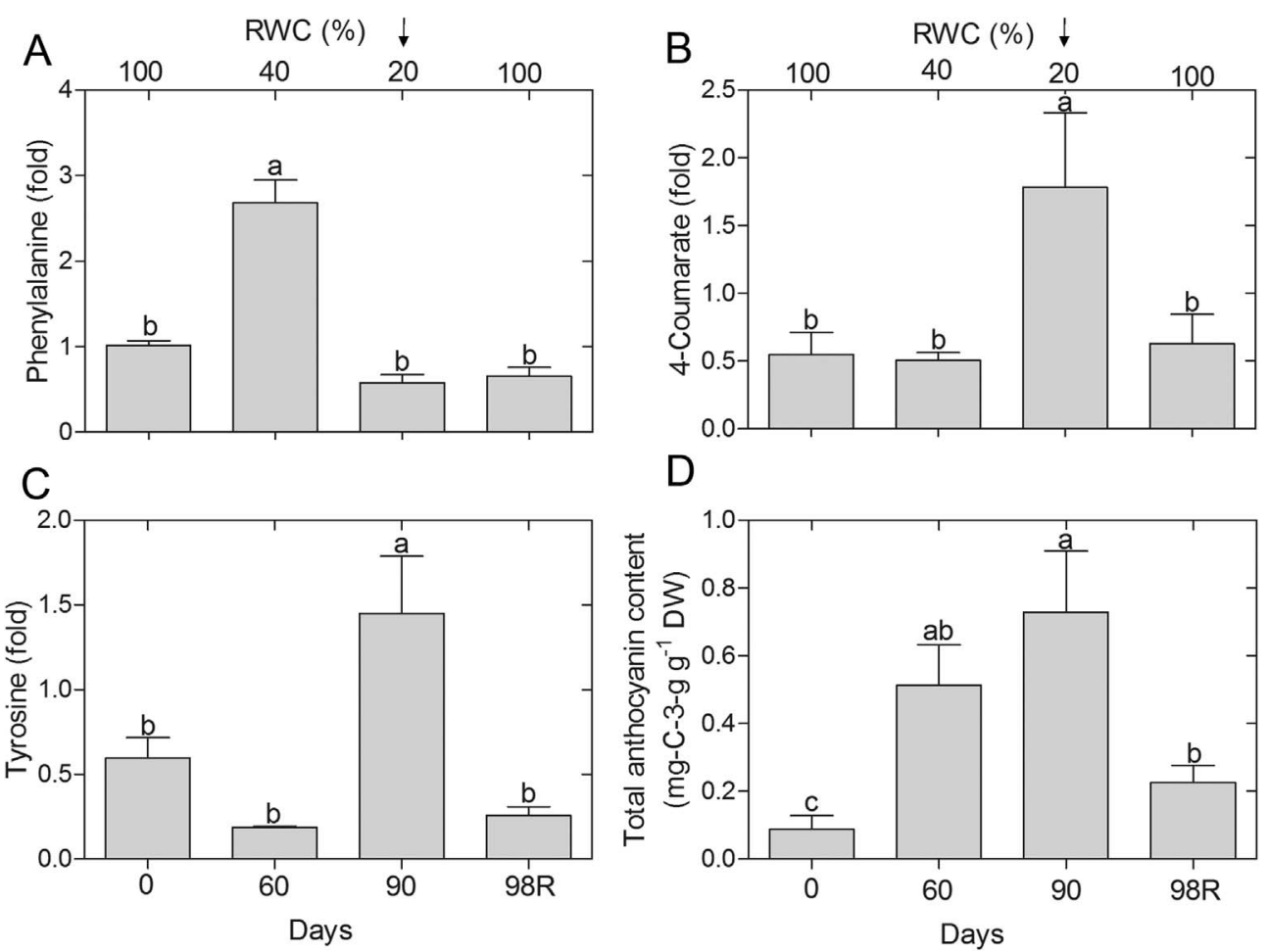

Fig. 1. Phenylalanine (A), 4-coumarate (B), tyrosine (C) and total anthocyanin (D) content in leaves of $P$. burchellii submitted to desiccation for 90 days and subsequent rehydration. The arrow indicates the day of resumption of irrigation and $\mathrm{R}$ : rehydrated plants. RWC indicates the relative water content of the leaves for each time of analysis. Different letters indicate significant differences among periods at $\mathrm{p} \leq 0.05$ by Tukey test.

\section{D}



days of dessication and after rehydration, using the methanolic-insoluble residue (item 2.5). The material was suspended in $90 \%$ dimethylsulfoxide (DMSO) and incubated with amiloglucosidade (AMG) (one enzyme unit to $10 \mathrm{mg}$ ) for starch removal. The remaining residue was washed thoroughly with distilled water and lyophilized. The samples were then washed twice with $10 \mathrm{ml}$ of $100 \mathrm{mM}$ potassium phosphate buffer $\mathrm{pH} 7.0$, and subsequently with $10 \mathrm{ml}$ of chloroform: methanol $(\mathrm{v} / \mathrm{v}), 10 \mathrm{ml}$ acetone and $10 \mathrm{ml}$ of ethyl ether. At each step, the material was washed with distilled water, centrifuged and the supernatants were discarded. The final residue was subjected to drying at $60{ }^{\circ} \mathrm{C}$ for $72 \mathrm{~h}$ (Gorshkova et al., 1996). For cell wall glycosyl composition analysis, about $300 \mu \mathrm{g}$ of material were hydrolyzed in methanolic $\mathrm{HCl}$ in sealed tubes for $18 \mathrm{~h}$ at $80{ }^{\circ} \mathrm{C}$. After cooling and removal of solvent under $\mathrm{N}_{2}$ flow, the samples were treated with a mixture of methanol, pyridine and acetic anhydride, and solvents were evaporated and derivatized using Tri-Sil (Pierce) at $80{ }^{\circ} \mathrm{C}$ for $30 \mathrm{~min}$. The analysis of the trimethylsilyl glycosides were performed on a chromatograph (Agilent 7890A) coupled with a mass spectrometer (model 5975C), and molar percentage of the sugars was calculated from the identified peak areas in the chromatograms. For glycosidic linkage analysis, samples were permethylated, reduced and acetylated, depolymerized with alditol acetates and the partially methylated resultant was analyzed as described by Heiss et al. (2009). About $1 \mathrm{mg}$ of sample was suspended in $200 \mu \mathrm{l}$ of dimethylsulfoxide and stirred for 3 days. Samples were permethylated by two subsequent treatments with $\mathrm{NaOH}(15 \mathrm{~min})$ and methyl iodide (45 min). Following, the samples were hydrolyzed, permethylated with $2 \mathrm{M}$ trifluoroacetic acid (TFA) for $2 \mathrm{~h}$ at $121{ }^{\circ} \mathrm{C}$ in sealed tubes. Subsequently, they were reduced with deuterated sodium borohydride and acetylated using acetic acid and TFA. The partially methylated alditol acetates were analyzed on an Agilent 7890A chromatograph coupled with a mass spectrometer 5975C (electronic impact ionisation mode), using a capillary column Supelco SP-2331 (30 m).

\subsection{Anatomical analysis}

Samples taken from the middle portion of leaves and rhizomes from hydrated plants, from desiccated plants at 90 days of experiment and from rehydrated plants, $8 \mathrm{~d}$ after rehydration (98 days) (three samples per organ, per treatment) were fixed in FAA 50 (37\% formaldehyde, glacial acetic acid, 50\% ethanol, 1:1:18 v/v) (Johansen, 1940) and then transferred to $70 \%$ ethanol, except for the dehydrated material, which was transferred to $100 \%$ ethanol to avoid rehydration. Alternatively, dehydrated plants were also submitted to an increasing ethanolic series (70-100\%) in order to demonstrate that the observed anatomical differences were due to the imposed environmental conditions and not to the differentiated dehydration process mentioned above.

After dehydration in 80, 90, and 100\% ethanol, samples were embedded in (2-hydroxyethyl)-methacrylate (Leica Historesin Embedding Kit) (Gerrits and Smid, 1983), and sectioned at 4-8 $\mu \mathrm{m}$ on a rotary microtome (Leica RM 2245) for light microscopy analyses. Sections were stained with periodic acid-Schiff's reagent (PAS) and toluidine blue and mounted on slides using Entellan (Merck). Handmade sections were also obtained using a razor blade, and bleached with $20 \%$ sodium hypochlorite, followed by staining with Astra blue and safranin, and mounting on slides with glycerine. The following histochemical tests were also performed: $5 \%$ tannic acid and $3 \% \mathrm{FeCl}_{3}$ for mucilage (Pizzolato and Lillie, 1973), and ruthenium red for pectin (Chamberlain, 1932). The images were obtained with a microscope (Leica, DM 4000B) equipped with a camera (Leica, DFC 450), using the software LAS (Leica Application Suite Version 4.0.0). The schematic representation of a dehydrated leaf was edited using the Microsoft Office PowerPoint 2007 and Adobe Photoshop CS6 (v. 13.0 Extended). Morphometric analysis was performed using IMAGEJ software (http:// imagej.nih.gov).

\subsection{Statistical analysis}

Biochemical parameters and morphometric analyses data were subjected to ANOVA and any contrast between means was evaluated by Tukey test $(\mathrm{P} \leq 0.05)$, using the statistical package Assistat Software Version 7.7. 
3. Results

\subsection{Phenylpropanoid pathway metabolites}

Phenylalanine content increased significantly $(62.4 \%)$ at 60 days (Fig. 1A), while enhancements of $62 \%$ and $37 \%$ were observed, respectively, in the 4-coumarate (Fig. 1B) and tyrosine concentrations (Fig. $1 \mathrm{C}$ ) at 90 days. After rehydration, these compounds reached values similar to the control group.

\subsection{Anthocyanins}

After 40 days of water deficit imposition, foliar border winding towards the central vein was observed in leaves of $P$. burchellii due to the decrease in RWC. Close to the main vein, changes in the composition of foliar pigments were also detected with appearance of bands of reddish cells with increase in the content of anthocyanins. Indeed, increases of 5.8 and 8.3 times were detected in the total anthocyanin content in the leaves at 60 and 90 days from the beginning of water suppression (T0), respectively. After rehydration, anthocyanin content decreased (Fig. 1D).

\subsection{Proline, phenols and antioxidant activity}

Increases of 2.4 times and 5.4 times in the proline content were observed, respectively, at 60 days in leaves and at 90 days in the rhizomes, following the decrease in RWC (Fig. 2A). Proline levels decreased in both organs after rehydration, reaching values close to that of the hydrated plants. The content of phenolic compounds was higher in leaves than in rhizomes. Increased phenol content was observed with the intensification of the water deficit reaching maximum values of $73.2 \mathrm{mg} \mathrm{g}^{-1} \mathrm{DW}$ at 90 days of water withholding. In the rhizomes, the total phenolic content increased significantly to $32.8 \mathrm{mg} \mathrm{g}^{-1} \mathrm{DW}$ only at 90 days of desiccation (Fig. 2B). After rehydration, the amount of total phenols decreased significantly in the rhizomes but a lower decrease was observed in leaves compared with rhizomes (Fig. 2B).

Decrease in leaf RWC were followed by an increase in the antioxidant activity from 30 days on of water suppression (Fig. 2C). Higher antioxidant activity was observed in leaves when compared to the rhizomes, with an increase of $28.7 \%$. A significant relation between RWC and antioxidant activity was only observed at 60 days of water withholding. Again, rehydration promoted a decrease in antioxidant activity in both organs (Fig. 2C).

\subsection{Monosaccharide and glycosyl linkage composition of leaf cell walls}

Total carbohydrate content of leaf cell walls of $P$. burchelli was around $20-25 \%$ in plants submitted to desiccation for 90 days, and decreased to about $17 \%$ after rehydration. The analyses of the composition of the non-cellulosic polysaccharides present in leaf cell walls revealed xylose as the predominant monosaccharide, making up more than $80 \%$ of the total carbohydrates. Arabinose was the second most abundant sugar, representing ca. $15 \%$, followed by glucose and galactose with less than $4 \%$ (Table 2). This proportion of monosaccharides is indicative of the presence of arabinoxylan as the major non-cellulosic polysaccharide in leaves. The arabinose/xylose ratio found in leaves before desiccation (0.16) increased in leaves submitted to water deficit at $60(0.19)$ and 90 days (0.18), suggesting the presence of more branched molecules containing arabinose in the dried-plants. Rehydration caused a reduction in the arabinose ratio, indicating a decrease in the substitution of arabinoxylan. Glycosyl-linkage analysis confirmed the presence of a 4-linked arabinoxylan (high proportion of 4-Xyl residues) as the major hemicellulose found in leaf cell walls and showed that this polysaccharide is substituted at the $0-2,0-3$ and $0-2,3$ by arabinose residues, as deduced by the proportions of 2,4-Xyl, 3,4-Xyl and 2,3,4-Xyl residues (Table 3). The reduction in arabinose

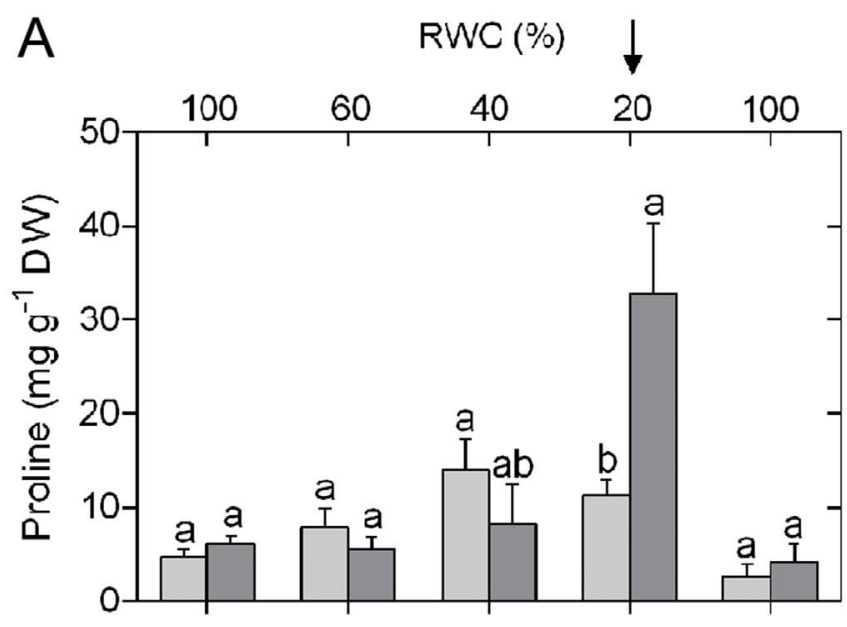

$\mathrm{B}$

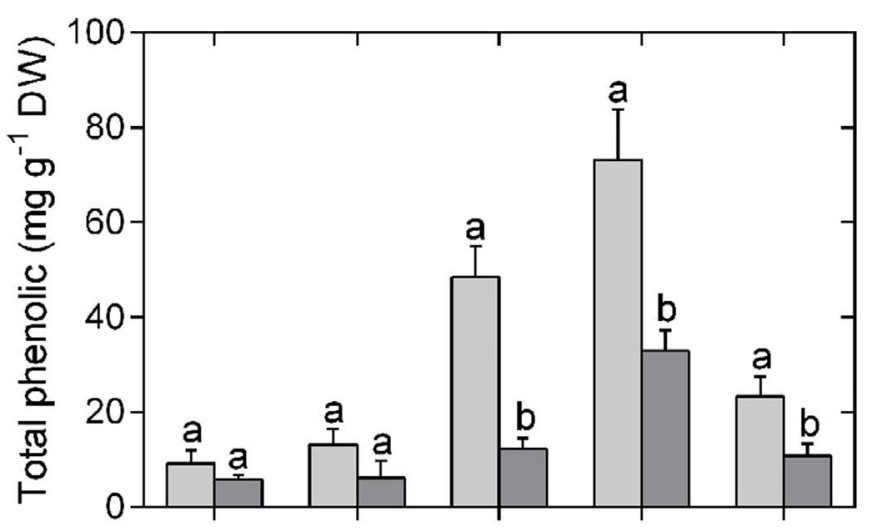

C

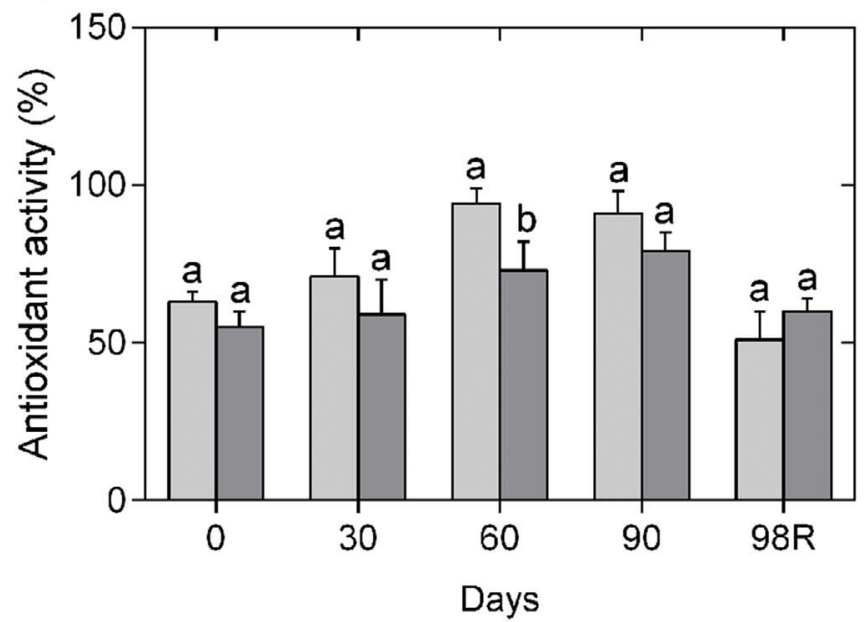

Fig. 2. Proline (A), total phenols (B) and antioxidant activity (C) in leaves (Light bars) and rhizomes (dark bars) of $P$. burchellii submitted to desiccation for 90 days and subsequent rehydration. The arrow indicates the day of resumption of irrigation and R: rehydrated plants. RWC indicates the relative water content of the leaves for each time of analysis. Different letters indicate significant difference among organs at $p \leq 0.05$ by Tukey test.

substitution after the hydration of dried leaves is suggested by the data presented in Table 3 and is consistent with the decrease in the ratio of the 3,4-Xyl and 2,3,4-Xyl residues observed by the glycosidic composition analyses. Apparently, the reduction of substitution occurs in the residues that are substituted at the $0-3$ position and simultaneously at 
Table 1

Anatomical changes in leaves and rhizomes of $P$. burchellii submitted to different water availability.

\begin{tabular}{|c|c|c|c|c|}
\hline & \multirow[t]{2}{*}{ Tissues or regions } & \multicolumn{3}{|l|}{ Treatments } \\
\hline & & Hydrated material & Dehydrated material & Rehydrated material \\
\hline \multirow[t]{3}{*}{ Leaves } & Adaxial epidermis & - Cells with slightly thickened walls & $\begin{array}{l}\text { - Cells with thickened, lignified walls and } \\
\text { anthocyanin presence }\end{array}$ & - Cells with thickened, lignified walls \\
\hline & Water-storage tissue & - Few layers of turgid cells & $\begin{array}{l}\text { - Several layers of plasmolised cells with } \\
\text { sinuous walls }\end{array}$ & - Several layers of turgid cells \\
\hline & Chlorenchyma & $\begin{array}{l}\text { - Cells with centralized vacuoles and high } \\
\text { chlorophyll content }\end{array}$ & $\begin{array}{l}\text { - Cells with polarized vacuoles and low } \\
\text { chlorophyll content }\end{array}$ & $\begin{array}{l}\text { - Cells with centralized vacuoles and high } \\
\text { chlorophyll content }\end{array}$ \\
\hline Rhizomes & $\begin{array}{l}\text { Pith } \\
\text { Cortex }\end{array}$ & $\begin{array}{l}\text { - Large and abundant starch grains } \\
\text { - Large and abundant starch grains }\end{array}$ & $\begin{array}{l}\text { - Large and abundant starch grains } \\
\text { - Large and abundant starch grains }\end{array}$ & $\begin{array}{l}\text { - Small and scarce starch grains } \\
\text { - Small and few starch grains } \\
\text { - Occurrence of cell divisions and intercellular } \\
\text { spaces rich in pectin }\end{array}$ \\
\hline
\end{tabular}

Table 2

Sugar composition of cell walls of $P$. burchellii leaves submitted to desiccation for 90 days and subsequent rehydration. $\mathrm{R}=$ rehydrated plants.

\begin{tabular}{lllll}
\hline \multirow{2}{*}{ Days } & 0 & 60 & 90 & $\mathrm{R}$ \\
\cline { 2 - 5 } & Mol (\%) & & & \\
\hline Carbohydrate content & 22.9 & 26.5 & 27.1 & 17.4 \\
Arabinose & 14.0 & 15.4 & 15.3 & 13.0 \\
Xylose & 83.4 & 80.8 & 83.1 & 82.1 \\
Galactose & 0.5 & 0.7 & 0.4 & 0.4 \\
Glucose & 2.1 & 3.0 & 1.2 & 1.1 \\
\hline
\end{tabular}

Table 3

Glycosyl linkage composition in the cell walls of $P$. burchellii leaves submitted to desiccation for 90 days and subsequent rehydration. $\mathrm{R}=$ rehydrated plants.

\begin{tabular}{|c|c|c|c|c|}
\hline Days & 0 & 60 & 90 & $\mathrm{R}$ \\
\hline Glycoside linkage & Mol (\%) & & & \\
\hline$t$-Araf & 7.9 & 10.2 & 8.9 & 9.1 \\
\hline t-Arap & 2.4 & 2.6 & 2.6 & 3.2 \\
\hline 2-Araf & 0.9 & 1.0 & 1.3 & - \\
\hline$t$-Glcp & 1.6 & 2.8 & 0.6 & 1.1 \\
\hline 3-Araf & 0.9 & - & - & - \\
\hline$t$-Galp & $<0.1$ & 0.2 & 0.6 & $<0.1$ \\
\hline 4-Arap or 5-Araf & 1.8 & 1.5 & 2.6 & 0.7 \\
\hline 4-Xylp & 60.9 & 60.1 & 49.9 & 69.7 \\
\hline 3-Glcp & 0.2 & 0.2 & - & - \\
\hline 2,4-Xylp & 4.5 & 4.7 & 5.5 & 6.0 \\
\hline $3,4-\mathrm{Xyl} p$ & 12.0 & 12.0 & 13.0 & 6.0 \\
\hline 3,4-Galp & 0.2 & 0.3 & 0.2 & 0.2 \\
\hline 3,4,6-Glcp & - & - & 0.3 & - \\
\hline 2,4-Glcp & 0.3 & - & 0.3 & - \\
\hline 4,6-Galp & 0.3 & 0.2 & 0.1 & 0.1 \\
\hline $2,3,4-\mathrm{Xyl} p$ & 6.0 & 4.0 & 14.7 & 3.4 \\
\hline 4-Manp $p^{\mathrm{a}}$ & $(1.4)$ & $(0.9)$ & (1.4) & $(0.6)$ \\
\hline 4-Glcp $p^{\mathrm{b}}$ & $(64.1)$ & (68.7) & (63.7) & (74.6) \\
\hline $2,4-\mathrm{Rhap}^{\mathrm{a}}$ & - & $(0.1)$ & $(0.3)$ & - \\
\hline
\end{tabular}

${ }^{a}$ Monosaccharides not detected by the analysis of glycoside composition.

${ }^{\mathrm{b}}$ Corresponding cellulose linkage.

the $0-2$ and 3 positions.

Arabinans 0-4 and 0-5 linked also make up the sugar moiety of the cell wall, as suggested by the ratios of 4-Ara and 5-Ara residues, but in much smaller amounts than arabinoxylans. The values of 4-Glc refer to the residues found in the cellulose (Table 3), which varied among treatments, but these changes in the cellulose proportions could not be related to desiccation and rehydration events.

\subsection{Anatomical characterization}

Two types of leaves form the rosette in plants of $P$. burchelli: photosynthesizing leaves and modified leaves that are narrow-lanceolate, coriaceous and spinous (Fig. 4A). Anatomically, the photosynthesizing leaves are dorsiventral (Fig. 3A-F). The epidermis is one-layered and covered by a thin cuticle (Fig. 3D-G). The abaxial epidermis is composed of cells with U-shaped thickened walls (Fig. 3D-G). The adaxial epidermis presents cells with slightly thickened walls in the hydrated leaves (Fig. 3D) whereas in dehydrated (Fig. 3E) and rehydrated leaves (Fig. 3F) cells have thickened and lignified walls. The epidermal cells facing the vascular bundles are completely thickened and lignified in both leaf surfaces regardless of the treatment (Fig. 3D). Peltate scales occur only on the abaxial leaf surface and are composed of basal cells, a two-celled stalk wholly immersed in the epidermis, and a wide multicellular shield (Fig. 3E). The stomata are also restricted to the abaxial leaf surface, in epidermal furrows, and the stomatal chambers are reduced (Fig. 3G).

Immediately beneath adaxial epidermis there is a multilayered hypodermis composed of rounded, colorless, thin-walled cells, forming a $\mathrm{V}$ deep water-storage tissue (Fig. 3A-F, K). The thickness and number of cell layers of water-storage tissue are significantly greater in dehydrated and rehydrated leaves compared with hydrated leaves (Fig. 3L). In the dehydrated leaves, the hypodermal cells are plasmolysed, with sinuous walls, mainly in the inner cell layers of hypodermis (Fig. 3B, E). The abaxial hypodermis consists of only one to two cell layers, with small, thin-walled cells, some of them containing anthocyanin (Fig. 3E-G).

The chlorenchyma is composed of two to four distinct palisade layers of compact, extended cells (Fig. 3E) above a loose tissue presenting small air channels filled with stellate cells with short arms (Fig. 3G). Vacuoles of chlorenchyma cells of hydrated and rehydrated leaves are centralized (Fig. $3 \mathrm{H}$ ), whereas those of chlorenchyma cells of dehydrated leaves are polarized (Fig. 3I-arrow). Idioblasts containing raphides and polysaccharides occur in the chlorenchyma (Fig. 3E, Fasterisk).

The vascular bundles are arranged in a single row, close to the abaxial surface (Fig. 3A-C). They are collateral and surrounded by a double sheath: the outer one is parenchymatous and the inner one is fibrous (Fig. 3D, F, J). Besides the central bundle, there are two other larger vascular bundles support ed by abaxial and adaxial surface layers delimiting the central region of the lamina (Fig. 3A-C, K-arrow heads). Such bundles have a well-developed adaxial fibrous sheath (Fig. 3J) and support the water-storage tissue when the leaves curl upwards under desiccation (Fig. 3K). Interestingly, the vascular bundles of dehydrated and rehydrated leaves are more strongly stained with safranin, indicating that desiccation induced lignin accumulation (Fig. 3A, C, J).

The rhizomes have a single-layered epidermis (Fig. 4B). The epidermal cells present thin walls and a smaller lumen compared to that of 

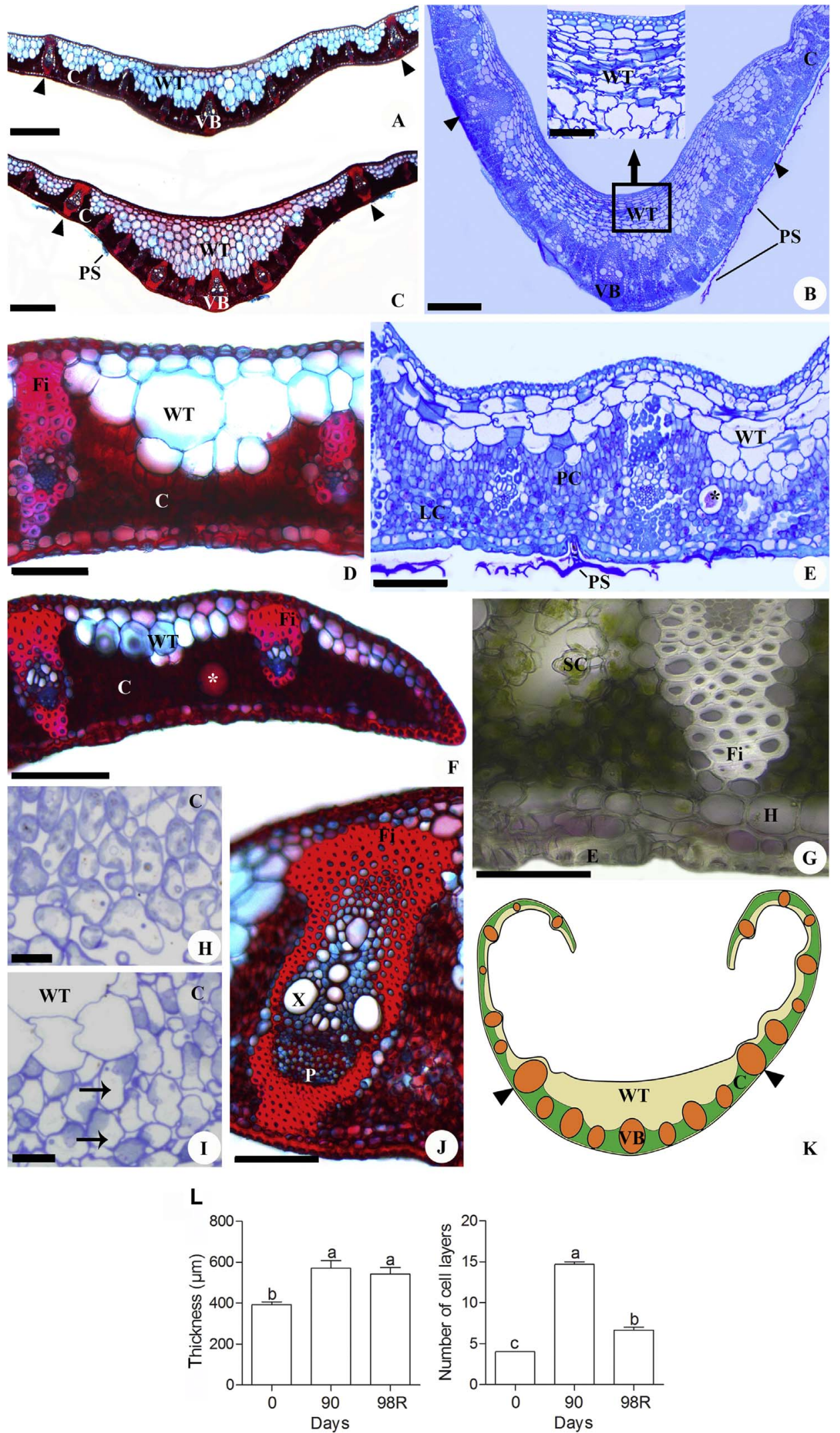

Fig. 3. Anatomical aspects of hydrated $(\mathbf{A}, \mathbf{D}, \mathbf{G}, \mathbf{H})$, dehydrated (B, E, I-K), and rehydrated (C, F) leaves of $P$. burchellii, in cross sections (A-C). General aspect of the leaf blade central region. D, E. Detail of the mesophyll in a region close to the leaf margin. F. Leaf margin. G. Detail of the adaxial epidermis, hypodermis, and chlorenchyma. H, I. Detail of chlorenchyma cells, showing polarized vacuole and compression of cytoplasmic structures in dehydrated leaves. J. Detail of a larger, lateral vascular bundle. K. Schematic representation of the leaf blade showing its winding. L. Thickness and number of cell layers of water-storage tissue during desiccation and rehydration. The results are presented as the mean SD from one experiment with 3 biological replicate per treatment. Different letters indicate significant differences. (E, epidermis; C, chlorenchyma; Fi, fibers; H, hypodermis; LC, loose chlorenchyma; P, phloem; PC, palisade chlorenchyma; PS, peltate scale; SC, stellate cell with short arms; VB, vascular bundle; WT, water-storage tissue; $\mathrm{X}$, xylem; *, idioblast; Arrows, polarized vacuoles; Arrow heads, lateral bigger vascular bundles that support the adaxial $\mathrm{V}$ deep water-storage tissue). Scale bars: $500 \mu \mathrm{m}$ (A-C); $100 \mu \mathrm{m}$ (B-detail, E, F); $50 \mu \mathrm{m}(\mathrm{D}, \mathrm{G}-\mathrm{J})$ the cortical cells (Fig. 4B). They usually contain silica bodies and are covered by a thin cuticle (Fig. 4B). The cortex is parenchymatous and has leaf traces (Fig. 4C-I). The cortical cells contain starch grains (Fig. 4C-H), except in the inner layers of the cortex (Fig. 4B). The vascular cylinder is delimited by a multilayered pericycle, which is composed of thin-walled cells (Fig. 4C-E). The vascular bundles are collateral, simple or compound, and are randomly arranged in a parenchymatous pith (Fig. 4C-E, J, K). Idioblasts containing raphides and polysaccharides occur in both, cortex and pith (Fig. 4C, E, F, H-J).

Cortex and pith cells also contain starch grains. Morphometric 



G)
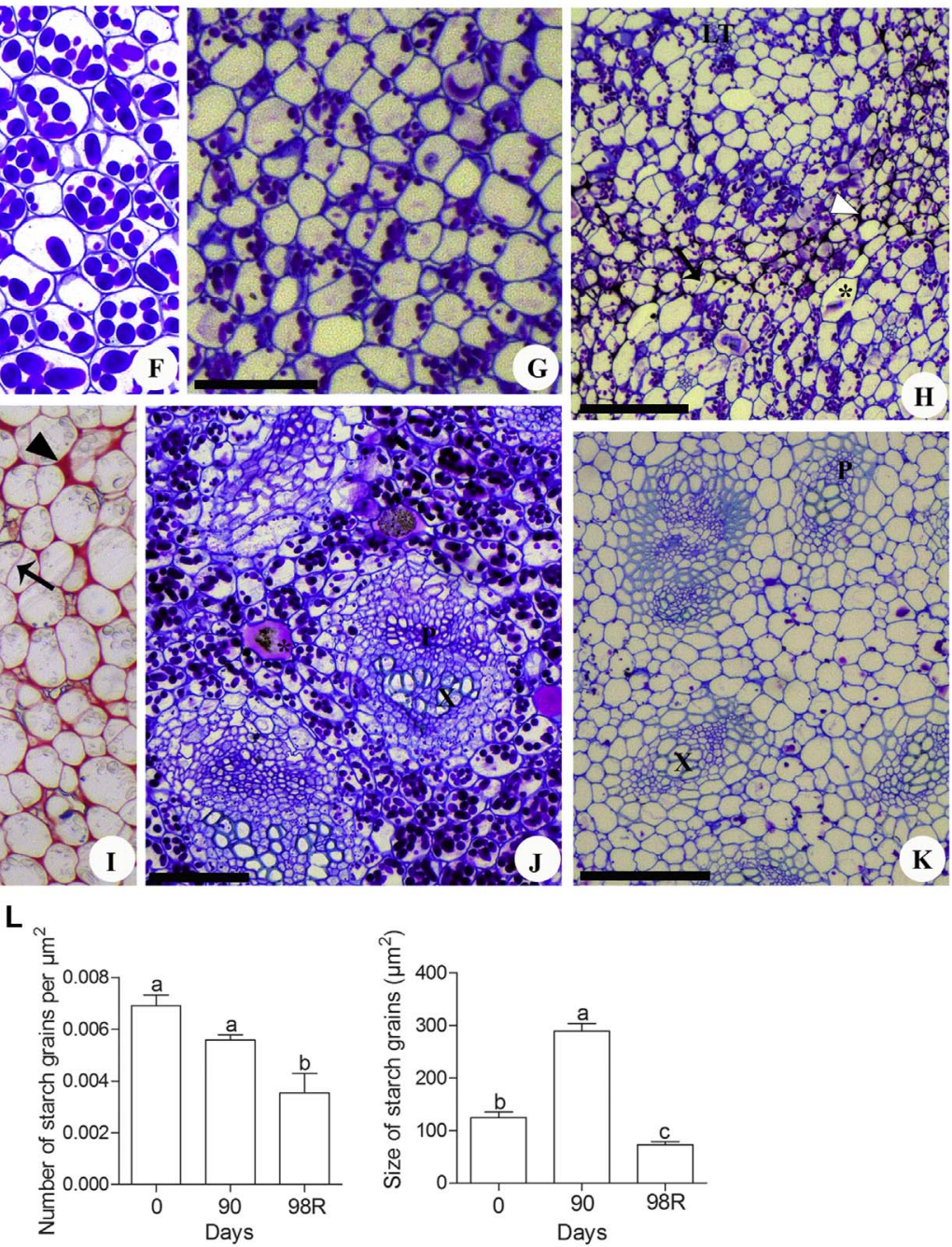

Fig. 4. Morphological (A) and anatomical aspects (cross sections) of hydrated (C, J), dehydrated (B, D, F), and rehydrated (E, G-I, K) rhizomes of $P$. burchellii. A. Detail of the rosette in a dehydrated plant. B. Detail of the epidermis and cortex (C-E). Detail of the cortex and vascular cylinder. F, G. Detail of the cortex, showing the starch grains. H, I. Detail of the cortex, showing cell divisions (arrow) and intercellular spaces rich in pectin (arrow heads). J, K. Detail of the pith, showing the vascular bundles. L. Number and size of starch grains during desiccation and rehydration. The results are presented as the mean SD from one experiment with 10 cortical cells per treatment. Different letters indicate significant differences. (C, cortex; LS, leaf sheath; LT, leaf trace; ML; modified leaf; P, phloem; Pe, pericycle; Pi, pith; PL, photosynthesizing leaf; SB, silica bodies; VB, vascular bundle; X, xylem; *, idioblast). Scale bars: $1 \mathrm{~cm}(\mathrm{~A}) ; 200 \mu \mathrm{m}$ (B, H, J, K); $500 \mu \mathrm{m}(\mathrm{C}-\mathrm{E}) ; 100 \mu \mathrm{m}$ (F, G, I). analysis showed differences in number and size of starch grains in cortical cells of dehydrated and rehydrated rhizomes. Water restriction significantly increased the size of starch grains in the rhizomes (Fig. 4C, J), although starch amount remained unchanged (Fig. 4D, F, L). However, after rehydration both number and size of the grains were significantly reduced, indicating starch mobilization (Fig. 4E, G, H, K, L). In the cortex of rehydrated rhizomes cell divisions and intercellular spaces rich in pectin were observed (Fig. $4 \mathrm{H}$ and I). The anatomical changes observed in the hydrated, dehydrated, and rehydrated material are summarized in Table 1. 


\section{Discussion}

The ability of Pitcairnia burchellii to tolerate desiccation for extended periods involves biochemical and structural changes in its leaves and rhizomes. These changes seem to be part of two distinct strategies. The first one is related to the maintenance of osmotic equilibrium and protective functions against ROS during drought. The second is based on the use of carbon/nitrogen-rich compounds for the regrowth after rehydration.

The anatomical analysis also confirmed that in $P$. burchellii, the rhizomes function as storage organs during the water stress, since larger and more abundant starch grains were observed in the rhizomes of dehydrated plants. On the other hand, in the cortical region of rehydrated rhizomes, morphometric analysis showed a significant reduction in size and number of starch grains, pointing to the mobilization of this carbohydrate. Indeed, after rehydration, the starch grains were rapidly metabolized, especially those of the pith, which are considerably smaller. In agreement with this observation, starch quantification by colorimetric assay revealed that starch mobilization in the leaves and rhyzomes of $P$. burchellii occurs during dehydration, suggesting that it seems to be an important osmoregulatory mechanism in this species (Vieira et al., 2017b). Starch is an important polysaccharide involved in the osmotic equilibrium, regulating metabolic activities during maintenance and repair of leaf tissues, as well as for the development of new leaves (Appezzato da Glória, 2015). Thus, the increased use of hydrolysis product in the rehydrated plants is probably related to the restoration of the plant aerial part, including the unwinding of the leaf blade and the repair of the photosynthetic tissue. As observed in other species, the metabolized sugars provide energy and carbon supply for the recovery of the metabolism in rehydrated organs (Norwood et al., 2003).

In $P$. burchellii, starch mobilization occurred concomitantly with cell division and accumulation of pectic polysaccharides in the cortical region of rehydrated rhizomes. Large amounts of pectic polysaccharides are able to form hydration zones, which provide a suitable microenvironment allowing cell division (Leroux et al., 2007). This accumulation is consistent with previous observations that the formation of pectin-rich zones is important to provide rapid rehydration and precedes events of cell division and expansion (Leroux et al., 2007). This fact confirms the existence of a second strategy, when plants of $P$. burchellii are submitted to very long periods of drought, mobilizing starch for the production of new tissues rather than the recovery of preexisting ones.

Leaves of $P$. burchellii also showed modified cell wall chemical composition after rehydration. The high content of arabinose-containing polymers detected in the leaves provides greater flexibility to the cell walls during desiccation. According to Moore et al. (2013), arabinoxylans function as "plasticizers", acting as dispersants polymer blends to increase the plasticity and/or flow ability, providing mechanical stabilization to the cell wall. A study with bromeliads of the genus Aechmea reported that glucoronoarabinoxylans (GAXs) were the most abundant non-cellulosic polysaccharide in cell walls and its structure was strongly related to the greater resistance of the chlorenchyme walls (Ceuters et al., 2008). These authors emphasize that xylose chains that presented lower substitution by arabinose polymers in cell walls were more resistant to cell disruption, implying a higher mechanical resistance, with greater possibility of withstanding internal pressures during the inflow of water.

In $P$. burchellii, the cells of water-storage tissue of hydrated leaves were rounded and turgid, whereas those of dehydrated leaves were flaccid, resulting in the upward curling of leaf blades. During the desiccation process, the larger, lateral lignified vascular bundles seem to play a supporting function, sustaining the central region of the leaf blade. The later has a more developed water-storage tissued when compared to hydrated leaves, allowing a rapid rehydration of the tissue.

Thus, in P. burchellii arabinose polymers appear to play an important role in maintaining the flexibility of the cell wall during the leaf folding in dehydrated plants, whereas xylose chains provide resistance to the high pressure during the rehydration process. In leaves of Craterostigma wilmsii (Scrophulariaceae), a significant increase in pectins and xyloglucans led to a change in the mechanical properties of the cell walls, allowing their folding and avoiding cell collapse in the dry state (Vicré et al., 2004).

When leaves curl, its abaxial surface and consequently the stomata become more exposed, therefore the peltate scales with a wide shield are important to reduce water loss by transpiration and protect the leaf blade against sun radiation. The peltate scales of Bromeliaceae can also absorb water and nutrients (Brighigna et al., 1984; Benzing, 2000) what may represent an adaptive advantage for $P$. burchellii to cope with drought. It has been already demonstrated in Haberlea rhodopensis (Gesneriaceae), that leaves can absorb water as a complementary mechanism to survive long periods of drought (Péli et al., 2012). The presence of peltate scales, stomata restricted to the abaxial surface, idioblasts with raphides and water-storage tissue in the mesophyll are common characteristics of Bromeliaceae leaves (Tomlinson, 1969) and are related to the habit, since most of the species are epiphytic or rupicolous.

In our study, dehydrated and rehydrated leaves showed thicker and multilayered water-storage tissue compared to hydrated leaves. The increased number of cell layers prevents the contact of the underlying cells with the transpiration surface, suggesting a strategy to avoid excessive water loss during desiccation. This hypothesis is supported by the fact that the number of layers of this tissue decreases significantly after rehydration.

In leaves and rhizomes of $P$. burchellii, an increase in the proline content was initiated at 30 days and maintained up to 90 days of water witholding, possibly contributing to the osmotic equilibrium, structure protection and as a source of nitrogen after rehydration (Vieira et al., 2017a). Proline acts as a nitrogen reserve for the synthesis of specific enzymes and as a molecular chaperone, stabilizing protein structures and protecting cells against ROS accumulation (Vicré et al., 2004; Krasensky and Jonak, 2012). During dehydration of the desiccation tolerant plant Eragrostis nidenses (Poaceae), the accumulation of proline in small vacuoles and cytoplasm of the sheath cells of the vascular bundle contributed to the osmotic regulation and cellular stabilization (Vander-Willigen et al., 2004). Curiously, dehydrated leaves of $P$. burchellii showed proline accumulation and polarized vacuolization of chlorenchymatic cells, resulting in suppression of cytoplasmic structures, clearly observed in the anatomical analyses. The loss of vacuolar water induced plasmalemma retraction, resulting in cell wall tension and increasing compaction of organelles and macromolecules resulting in plasmolysis (Walters et al., 2002). The large central vacuole is divided into smaller vacuoles, in which water is replaced by compatible solutes, such as amino acids. These subcellular modifications are related to changes in the cell turgor that have already been observed in other resurrection plants (Farrant et al., 2003; Vicré et al., 2004; Moore et al., 2006).

Significant increases in precursors of secondary metabolites were observed during the desiccation of $P$. burchellii. Among these precursors are phenylalanine, 4-coumarate and tyrosine, all phenylpropanoid pathway intermediates, responsible in part for the synthesis of phenolic compounds, such as anthocyanin, flavonoids and lignin (Laursen et al., 2015). The increased content of these precursors was consistent with the significant increase of total phenolic compounds in leaves and rhizomes and with the leaf anthocyanin content detected in P. burchellii. Phenylpropanoid pathway intermediates represent a main course of carbon from primary to secondary metabolism, whose compounds are frequently involved in plant defense and stress acclimation (Zandalinas et al., 2017).

Anatomical analysis also showed anthocyanin accumulation predominantly in the abaxial hypodermis of $P$. burchellii leaves at 90 days, whose role has been related to the protective effect on light-induced 
oxidative damage during desiccation. Leaves exposed to light generally exhibit increased anthocyanin content on the abaxial surface during dehydration, which may function as a "sun screen", reflecting the excess of photosynthetically active radiation before and during chlorophyll degradation (Farrant et al., 2015). As shown by Vieira et al. (2017b), the degradation of chlorophylls in P. burchellii occurs concomitantly with the increase of carotenoids that, together with the accumulation of anthocyanins seen here, certainly protects photosynthetic machinery against photoinhibition.

Lignin accumulation was observed in the epidermal cells and vascular bundles of dehydrated and rehydrated leaves, contributing to the protection of the mesophyll and as a support to the tension imposed by the influx of water during rehydration. The activation of secondary metabolism in plants subjected to water restriction has been related to drought tolerance due to its potent antioxidant action, controlling the excessive production of ROS in tissues, therefore mitigating the damaging effects of desiccation (Agati and Tattini, 2010; Zandalinas et al., 2017).

The involvement of secondary metabolites as antioxidants was clearly shown in Larrea divaricata (Zygophyllaceae), a drought-tolerant species that occurs in arid Patagonian regions, in which the higher phenol production observed in leaves compared to roots was essential to maintain the balance between the production and the elimination of ROS (Varela et al., 2016). In P. burchellii, an efficient mechanism of ROS capture was demonstrated by the increase in antioxidant activity in leaves (greater than 90\%) and rhizomes (above 70\%) related to the increase of phenolic compounds. These results support the hypothesis that $P$. burchellii produces secondary metabolites that function as nonenzymatic antioxidants, as a mechanism to tolerate desiccation in their natural environment.

\section{Conclusion}

Here we demonstrated that $P$. burchellii was able to survive extended drought periods due to ROS-scavenging strategies, avoiding water loss during desiccation and accumulating reserve in the rhizome for the production of new tissues after rehydration. Overall, biochemical and structural changes observed in leaves and rhizomes during desiccation suggest that the xeromorphic characteristics of this bromeliad may be related to an evolutionary process to cope with drought by allowing it to behave as a resurrection species. These strategies can be a competitive advantage in environments under prolonged drought periods.

\section{Contributions}

E. Vieira, K. Silva and C. Moro performed the experiments. All authors designed the research, contributed to the data interpretation, discussion and paper writing. The final version of the manuscript was reviewed and approved by all authors.

\section{Acknowledgments}

The authors thank Fundação de Amparo à Pesquisa do Estado de São Paulo - FAPESP for the grant (2012/16332-0) and the Complex Carbohydrate Research Centre - CCRC, University of Georgia, USA for the cell wall analyses. E.A. Vieira thanks FAPESP (2012/14339-7) and K.R. Silva thanks CAPES for PhD fellowships. M.R. Braga thanks CNPq for a research fellowship. Thanks are due to Dr. Maria Angela M. Carvalho for English revision.

\section{References}

Abdel-Aal, E.-S.M., Huel, P., 1999. A rapid method for quantifying total anthocyanins in blue aleurone and purple pericarp wheats. Cereal Chem. 76, 350-354.

Agati, G., Tattini, M., 2010. Multiple functional roles of flavonoids in photoprotection. New Phytol. 186, 786-793.
Ainsworth, E.A., Gillespie, K.M., 2007. Estimation of total phenolic content and other oxidation substrates in plant tissues using Folin-Ciocalteu reagent. Nat. Protoc. 2, 875-877.

Appezzato da Glória, B., 2015. Morfologia de sistemas subterrâneos de plantas. 3i Editora, Belo Horizonte, pp. 160.

Bates, L.S., Waldren, R.P., Teare, I.D., 1973. Rapid determination of free proline for water-stress studies. Plant Soil 39, 205-207.

Benzing, D.H., 2000. Bromeliaceae: Profile of an Adaptative Radiation. Cambridge University Press, USA.

Brighigna, L., Fiordi, A.C., Palandri, M.R., 1984. Structural characteristics of mesophyll in some Tillandsia species. Phytomorphology 34, 191-200.

Carvalho, F., Souza, F.A., Carrenho, R., Moreira, F.M.S., Jesus, E.C., Fernandes, G.W., 2012. The mosaic of habitats in the high-altitude Brazilian rupestrian fields is a hotspot for arbuscular mycorrhizal fungi. Appl. Soil Ecol. 52, 9-19.

Ceuters, J., Londers, E., Brijs, K., Delcour, J.A., Proft, M.P.D., 2008. Glucuronoarabinoxylano structure in the wall of Aechmea leaf chlorenchyma cells is related to wall strength. Phytochemistry 69, 2307-2311.

Chamberlain, C.J., 1932. Methods in Plant Histology, $5^{\text {a }}$ ed. The University of Chicago Press, Chicago, pp. 416.

Dinakar, C., Bartels, D., 2013. Desiccation tolerance in resurrection plants: newinsights from transcriptome, proteome and metabolome analysis. Front. Plant Sci. 4, 1-14.

Farrant, J.M., Vander-Willigen, C., Loffell, D.A., Bartsch, S., Whittaker, A., 2003. An investigation into the role of light during desiccation of three angiosperm resurrection plants. Plant, Cell Environ. 26, 1275-1286.

Farrant, J.M., Cooper, K., Hilgart, A., Abdalla, K.O., Bentley, J., Thomson, J.A., Dace, H.J., Peton, N., Mundree, S.G., Rafudeen, M.S., 2015. A molecular physiological review of vegetative desiccation tolerance in the resurrection plant Xerophyta viscosa (Baker). Planta 242, 407-426.

Forzza, R.C., Cost,a, A., Siqueira-Filho, J.A., Martinelli, G., Monteiro, R.F., Santos-Silva, F., Saraiva, D.P., Paixão-Souza, B., Louzada, R.B., Versieux, L., 2015. Bromeliaceae in Lista de Espécies da Flora do Brasil. Jard. Botânico do Rio J. http://floradobrasil.jbrj. gov.br/jabot/floradobrasil/FB46706.

Franco, A.C., Rossatto, D.R., Silva, L.C.R., Ferreira, C.S., 2014. Cerrado vegetation and global change: the role of functional types, resource availability and disturbance in regulating plant community responses to rising $\mathrm{CO}_{2}$ levels and climate warming. Theor. Exp. Plant Physiol. 123, 1-21.

Gaff, D.F., Oliver, M., 2013. The evolution of desiccation tolerance in angiosperm plants: a rare yet common phenomenon. Funct. Plant Biol. 40, 315-328.

Gall, H., Philippe, F., Domon, J.-M., Gillet, F., Pelloux, J., Rayon, C., 2015. Cell wall metabolism in response to abiotic stress. Plants 4, 112-166.

Galmés, J., Flexas, J., Medrano, H., Niinemets, Ü., Valladares, F., 2012. Ecophysiology of photosynthesis in semi-arid environments. In: terrestrial photosynthesis in a changing environment. In: Flexas, J., Loreto, F., Medrano, H. (Eds.), A Molecular, Physiological, and Ecological Approach. Published by Cambridge University Press.

Gerrits, P.O., Smid, L., 1983. A new, less toxic polymerization system for the embedding of soft tissues in glycol methacrylate and subsequent preparing of serial sections. J. Microsc. 132, 81-85.

Gorshkova, T.A., Wyatt, S.E., Salnikov, V.V., Gibeaut, D.M., Ibragimov, M.R., Lozovaya, V.V., Carpita, N.C., 1996. Cell-wall polysaccharides of developing flax plants. Plant Physiol. 110, 721-729.

Heiss, C., Klutts, J.S., Wang, Z., Doering, T.L., Azadi, P., 2009. The structure of Cryptococcus neoformans galactoxylomannan contains beta-D-glucuronic acid. Carbohyd Res. 344, 15-20.

Hoekstra, F.A., Golovina, E.A., Tetteroo, F.A., Wolkers, W.F., 2001. Induction of desiccation tolerance in plant somatic embryos: how exclusive is the protective role of sugars? Cryobiology 43, 140-150.

Johansen, D.A., 1940. Plant Microtechnique. McGraw Hill Book, New York.

Krasensky, J., Jonak, C., 2012. Drought, salt and temperature stress-induced metabolic rearrangements and regulatory networks. J. Exp. Bot. 63, 1593-1608.

Laursen, T., Møller, B.L., Bassard, J.-E., 2015. Plasticity of specialized metabolism as mediated by dynamic metabolons. Trends Plant Sci. 20, 20-32.

Lawlor, D.W., Cornic, G., 2002. Photosynthetic carbon assimilation and associated metabolism in relation to water deficits in higher plants. Plant, Cell Environ. 25, 275-294.

Leroux, O., Knox, J.P., Leroux, F., Vrijdaghs, A., Bellefroid, E., Borgonie, G., Viane, R.L.L., 2007. Intercellular pectic protuberances in Asplenium: new data on their composition and origin. Ann. Bot. 100, 1165-1173.

Moore, J.P., Nguema-Ona, E., Chevalier, L., Lindsey, G.G., Brandt, W.F., Lerouge, P. Farrant, J.M., Driouich, A., 2006. Response of the leaf cell wall to desiccation in the resurrection plant Myrothamnus flabellifolius. Plant Physiol. 141, 651-662.

Moore, J.P., Nguema-Ona, E.E., Vicre'-Gibouin, M., Sorensen, I., Willats, W.G.T., Driouich, A., Farrant, J.M., 2013. Arabinose-rich polymers as an evolutionary strategy to plasticize resurrection plant cell walls against desiccation. Planta 237, 739-754.

Moraes, M.G., Carvalho, M.A.M., Franco, A.C., Pollock, C.J., Figueiredo-Ribeiro, R.C.L., 2016. Fire and drought: soluble carbohydrate storage and survival mechanisms in herbaceous plants from the cerrado. BioScience 66, 107-117.

Mundree, S.G., Baker, B., Mowla, S., Peters, S., Marais, S., Vander-Willigen, C., Govender, K., Maredza, A., Farrant, J.M., Thomson, J.A., 2002. Physiological and molecular insights into drought tolerance. Afr. J. Biotechnol. 1, 28-38.

Norwood, M., Toldi, O., Richter, A., Scott, P., 2003. Investigation into the ability of roots of the poikilohydric plant Craterostigma plantagineum to survive dehydration stress. J. Exp. Bot. 54, 2313-2321.

Parmentier, I., 2003. Study of the vegetation composition in three inselbergs from continental Equatorial Guinea (western central Africa): effects of site, soil factors and position relative to forest fringe. Belg. J. Bot. 136, 63-72. 
Péli, E.R., Mihailova, G., Petkova, S., Tuba, Z., Georgieva, K., 2012. Differences in physiological adaptation of Haberlea rhodopensis Friv. leaves and roots during dehydration-rehydration cycle. Acta Physiol. Plant. 34, 947-955.

Pizzolato, P., Lillie, R.D., 1973. Mayer's tannic acid-ferric chloride stain for mucins. J. Histochem. Cytochem. 21, 56-64.

Roessner, U., Luedemann, A., Brust, D., Fiehn, O., Linke, T., Willmitzer, L., et al., 2001. Metabolic profiling allows comprehensive phenotyping of genetically and environmentally modified systems. Plant Cell 13, 131-142.

Tomlinson, P.B., 1969. III commelinales-zingiberales. In: Metcalfe, C.R. (Ed.), Anatomy of the Monocotyledons. Clarendon Press, pp. 193-294.

Vander-Willigen, C.V., Pammenter, N.W., Mundree, S., Farrant, J.M., 2004. Mechanical stabilization of desiccated vegetative tissues of the resurrection grass Eragrostis nindensis: does a TIP 3;1 and/or compartmentalization of subcellular components and metabolites play a role? J. Exp. Bot. 55, 651-661.

Varela, M.C., Arslan, I., Reginato, M.A., Cenzano, A.M., Luna, M.V., 2016. Phenolic compounds as indicators of drought resistance in shrubs from Patagonian shrublands
(Argentina). Plant Physiol. Biochem. 104, 81-91.

Vicré, M., Lerouxel, O., Farrant, J.M., Lerouge, P., Driouich, A., 2004. Composition and desiccation-induced alterations of the cell wall in the resurrection plant Craterostigma wilmsii. Physiol. Plant. 120, 229-239.

Vieira, E.A., Silva, M.G., Moro, C.F., Laura, V.A., 2017a. Physiological and biochemical changes attenuate the effects of drought on the Cerrado species Vatairea macrocarpa (Benth.) Ducke. Plant Physiol. Biochem. 115, 472-483.

Vieira, E.A., Centeno, D.C., Freschi, L., Silva, E.A., Braga, M.R., 2017b. The dual strategy of the bromeliad Pitcairnia burchellii Mez to cope with desiccation. Environ. Exp. Bot. 143, 135-148.

Walters, C., Farrant, J.M., Pammenter, N.W., Berjak, P., 2002. Desiccation and damage. In: Black, M., Pritchard, H. (Eds.), Desiccation and Survival in Plants: Drying without Dying. CAB International, London, pp. 263-291.

Zandalinas, S.I., Sales, C., Beltrán, J., Gómez-Cadenas, A., Arbona, V., 2017. Activation of secondary metabolism in citrus plants is associated to sensitivity to combined drought and high temperatures. Front. Plant Sci. 7, 1-17. 